Cuadernos de Historia Moderna

ISSN: 0214-4018

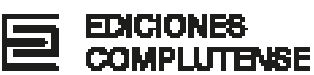

https://dx.doi.org/10.5209/chmo.78377

\title{
Las carreras eclesiásticas en la España moderna: ¿vocación o modo de vida?
}

Arturo Morgado García ${ }^{1}$

Recibido: 13 de enero de 2021 / Aceptado: 13 de octubre de 2021

Resumen. Se intenta realizar un análisis de las carreras eclesiásticas en la España moderna, determinando el peso del factor vocacional, e incidiendo en las posibles renuncias que podía conllevar el sacerdocio.

Palabras clave: Historia Moderna España; Siglo XVIII; Clero; Bajo clero secular; Vocación.

\section{[en] Ecclesiastical careers in Early Modern Spain: vocation or way of life?}

\begin{abstract}
We try to analyze ecclesiastical careers in Early Modern Spain, determining the weight of the vocational factor, and focusing on the possible renunciations that the priesthood career could entail. Keywords: Early Modern Spain; Eighteenth Century; Clergy; Lower Secular Clergy; Vocation.
\end{abstract}

Sumario: Las motivaciones: lo que dicen los interesados. La edad de ordenación: ¿vocación temprana o hastío del mundo? Muchos son los llamados y pocos los escogidos: la tasa de persistencia. ¿A qué se renunciaba?: La persistencia de los lazos familiares. ¿A qué se renunciaba?: Una mediana posición económica. Bibliografía.

Cómo citar: Morgado García, A. (2021). Las carreras eclesiásticas en la España moderna: ¿vocación o modo de vida?, en Cuadernos de Historia Moderna 46.2, 419-440.

Vocación. Por extensión se llama el oficio o carrera que se elige para pasar la vida, por armas, letras, o mecánica ${ }^{2}$. Así se definía en 1739 un término que en la actualidad consideramos muy ligado a la condición sacerdotal, y que en el Tesoro de la Lengua Castellana de Covarrubias, de 1611, ni siquiera aparece. Ello no quiere decir, naturalmente, que el concepto no existiera, por cuanto es empleado con profusión por la literatura religiosa y espiritual. No obstante, es poco habitual encontrar testimonios de primera mano, ya que, como ha señalado su mayor conocedor, Fernando Durán, la autobiografía religiosa es poco propicia a detenerse en el decurso

\footnotetext{
1 Universidad de Cádiz

ORCID: https://orcid.org/0000-0003-3849-8062

Email: arturo.morgadogarcia@uca.es

2 Diccionario de la lengua castellana ... compuesto por la Real Academia Española, tomo sexto, Madrid, Imprenta de la Real Academia Española, 1739, p. 512.
} 
vital anterior al ingreso en el estado eclesiástico, por lo que pocas noticias nos presta acerca de la infancia como escuela de aprendizaje de la santidad ${ }^{3}$. A todo ello hay que añadirle el hecho de que la gran mayoría de los textos conservados se refiere a religiosos, especialmente mujeres, no a seculares, que en muy pocas ocasiones nos informan de propia mano acerca de las circunstancias que les llevaron a abrazar la carrera eclesiástica, como el antiguo soldado Pedro Ordóñez de Cevallos (m. 1630), autor de una conocida autobiografía donde narra su periplo por todo el mundo conocido por aquel entonces.

Parece bien asentado que los flujos de ingreso en el estamento clerical no están determinados tanto por las orientaciones del discurso teológico cuanto por las condiciones de acceso a los beneficios eclesiásticos, la jerarquía económica de los mismos, y los sistemas de transmisión existentes ${ }^{4}$, como se planteara en cierto momento Guzmán de Alfarache:

No hallé otro mejor que acogerme a sagrado y díjeme. Yo tengo letras humanas. Quiero valerme de ellas, oyendo en Alcalá de Henares, pues la tengo a la puerta, unas pocas de artes y teología. Con esto me graduaré. Que podría ser tener talento para un púlpito, $\mathrm{y}$, siendo de misa y buen predicador, tendré cierta la comida, y, a todo faltar, meteréme a fraile 5 .

Y motivaciones similares encontraremos, a poco que se busquen, en la literatura del momento:

Y como antes de tomar el grado de bachiller en Teología era necesario tener órdenes y esto era imposible, por faltar capellanía, no tuve otro remedio que acudir a pedírselo a mi suegro... dijo que me haría donación de las posesiones de la dote de mi mujer, diciéndome dármelas para que se fundase cierta capellanía que yo sirviese por su alma, y que por otra parte le hiciese declaración de la verdad, obligándome a volvérselas cada y cuando que me las pidiese ${ }^{6}$.

Este era el hombre interior y exterior del tío Antón Zotes, el cual, aunque había llegado hasta el banco de abajo de medianos con ánimo de ordenarse, porque dicen que le venía una capellanía de sangre en muriendo un tío suyo, arcipreste de Villaornate, pero al fin le puso pleito una moza del lugar, y se vio precisado a ir por la iglesia mas no al coro ni al altar sino al santo matrimonio?.

Acometióle a mi padre a este tiempo la dichosa vocación de que yo fuese clérigo, y porque no se le resfriasen los propósitos, solicitó una capellanía en la parroquia de San Martín de Salamanca, cuya renta estaba situada en una casa de la calle de

Durán López, F.: Un cielo abreviado. Introducción crítica a la historia de la autobiografía religiosa en España, Madrid, FUE/Universidad Pontificia de Salamanca, 2007, p. 83.

$4 \quad$ Julia, D.: "El sacerdote", en Vovelle, M. y otros: El hombre de la Ilustración, Madrid, Alianza, 1995, pp. 359394.

5 Alemán, M.: Guzmán de Alfarache, edición de Francisco Rico, Barcelona, Planeta, 1987, 2ª edición, parte segunda, lib. 3, cap. 4 .

6 Ibidem.

7 Isla, J. F. de: Historia del famoso predicador Fray Gerundio de Campazas, ed. de L. Fernández Martín, Madrid, Editora Nacional, 1978, vol. 1, p. 122. 
la Rúa, y sobre esta congrua que eran seiscientos reales al año, recibí, luego que yo cumplí los veinte y uno de mi edad, el orden de subdiácono ${ }^{8}$.

Tales ansias por permanecer en el estado clerical se explican fácilmente: los privilegios de un estamento ya de por sí socialmente valorado y estimado, por cuanto la inclusión en sus filas garantizaba una serie de prerrogativas de índole fiscal (inmunidad de los bienes eclesiásticos, exención de alcabalas y cientos, y, posteriormente, millones), exclusión de derechos de hospedaje y de ciertas cargas y oficios, liberación del servicio militar, tribunales especiales en causas civiles y criminales, y, además, constituía un grupo (supuestamente) abierto al ascenso y al mérito en una sociedad estamental (teóricamente) cerrada a ello9. Aunque el discurso oficial era muy distinto: ingresar en el estado eclesiástico requería de una decisión personal que debía ir acompañada de unas cualidades y modos de vida que habrían de convertirse en señales de la vocación, las cuales no surgían de repente sino que se iban desarrollando de forma paulatina. Una vez descubiertas, había que asentarlas y fomentarlas. La vocación, por ello, necesitaba ser trabajada ${ }^{10}$.

\section{Las motivaciones: lo que dicen los interesados}

Por supuesto, habría que contrastar el discurso oficial con las palabras de los aspirantes a órdenes. María Luisa Candau nos cuenta cómo en la campiña sevillana dieciochesca las solicitudes de acceso a las órdenes sagradas solían reflejar la intención de "servir más a Dios nuestro señor y por ascender a las demás órdenes no siendo su ánimo eximirse de las justicias seglares ni otros fines humanos", aunque algunos añaden el deseo de ser ordenados por razones materiales, tales el mantenimiento de la familia, padres achacosos, madres viudas, hermanas doncellas o hermanos menores $^{11}$.

Por lo que se refiere a la diócesis de Cádiz, el 20 de agosto de 1715 el prelado Lorenzo Armengual de la Mota promulgaba un edicto en el cual se disponía el interrogatorio que debía formularse a los aspirantes a órdenes. En su disposición séptima, se ordenaba

se atienda mucho y ponga gran diligencia en indagar el fin que les mueve a hacerse clérigos, si es el dedicarse al servicio de Dios y culto divino con inclinación particular al estado eclesiástico. Y si reciben la prima tonsura no con ánimo y voluntad de ascender a órdenes mayores, sino por huir fraudulentamente de los jueces y jurisdicciones seculares, por eximirse de la carga de las contribuciones o por algunos pleitos que han tenido con los administradores de las rentas reales, o con sus padres, y tentando poner la hacienda en cabeza de su hijo ${ }^{12}$.

\footnotetext{
8 Torres de Villarroel, D.: Vida, ascendencia, nacimiento, crianza y aventuras, edición de Dámaso Chicharro, Madrid, Cátedra, 1984, p. 162.

9 Candau Chacón, M. L.: El clero rural de Sevilla en el siglo XVIII, Sevilla, Caja Rural, 1994, pp. 178 y ss.

10 Irigoyen López, A.: "Sobre el ingreso en el clero: a cuestas con la vocación y con las estrategias familiares en la España del siglo XVIII”, Revista de Historia Social y de las Mentalidades, 20, 2 (2016), pp. 101-131.

11 Candau Chacón, M. L.: La carrera eclesiástica en el siglo XVIII. Modelos, cauces y formas de promoción en la Sevilla rural, Sevilla, Universidad, 1993.

12 Archivo Diocesano de Cádiz (ADC), Secretaría, leg. 2, edictos manuscritos, 2.
} 
Hemos podido comprobar este hecho en las informaciones realizadas a los candidatos, ya que son numerosas las ocasiones en que los testigos son interrogados acerca de si el pretendiente quería ingresar en el estado eclesiástico para defraudar a la Hacienda real o escapar de las obligaciones militares, a lo que siempre respondían, por supuesto, negativamente, señalando el ardiente deseo que tenía el candidato de recibir las sagradas órdenes.

Para intentar averiguar las posibles motivaciones que podían animar a estos individuos hemos analizado los Memoriales de Órdenes, unidos muchas veces a las informaciones de vita, genere et moribus. Se trata de una petición del interesado en la que constan su nombre, edad, puesto que ocupa en la jerarquía eclesiástica, lugar de naturaleza y de vecindad, y, lo que más nos interesa, el motivo por el cual deseaba ingresar en el estado eclesiástico o ascender en el mismo. En 363 de un total de 923 expedientes consultados y fechados entre 1700 y 1834, se contienen estos memoriales.

Los motivos principales alegados por los aspirantes son para mejor servir a Dios o para mayor gloria de Dios $(51,7 \%)$, porque desea ascender $(23,1 \%)$, porque desea ser sacerdote o seguir en dicho estado $(14,8 \%)$, por ser su inclinación y/o haberlo anhelado siempre $(11,5 \%)$, y, finalmente, la alegación por parte del candidato de que reúne méritos suficientes para ordenarse, edad canónica, congrua suficiente, o estudios competentes $(23,9 \%)$. No obstante, hay importantes diferencias cronológicas.

Motivos alegados por los aspirantes a órdenes

\begin{tabular}{|l|r|r|r|r|}
\hline & $1700-1749$ & $1750-1799$ & $1800-1834$ & \multicolumn{1}{c|}{ TOTAL } \\
\hline Para servir a Dios o su mayor gloria & $71,8 \%$ & $50,0 \%$ & $17,3 \%$ & 188 \\
\hline Porque desea ascender & $20,5 \%$ & $20,0 \%$ & $30,6 \%$ & 84 \\
\hline $\begin{array}{l}\text { Desea ser sacerdote/seguir en el sacer- } \\
\text { docio }\end{array}$ & $9,1 \%$ & $12,5 \%$ & $27,5 \%$ & 54 \\
\hline $\begin{array}{l}\text { Ser su inclinación y haberlo anhelado } \\
\text { siempre }\end{array}$ & $5,4 \%$ & $11,2 \%$ & $23,4 \%$ & 42 \\
\hline Acceso beneficio/mantener familia & $8,6 \%$ & $6,2 \%$ & - & 21 \\
\hline Reúne méritos suficientes & $19,4 \%$ & $33,7 \%$ & $24,4 \%$ & 87 \\
\hline Otros & $5,4 \%$ & $1,2 \%$ & $18,3 \%$ & 30 \\
\hline Total memoriales & 185 & 80 & 98 & 363 \\
\hline
\end{tabular}

Nota: se pueden alegar varios motivos a la vez.

Todavía en la primera mitad del siglo XVIII el 8,6\% de los candidatos expresa sin pudor alguno el deseo de acceder a algún beneficio eclesiástico o mantener a su familia, lo que podría probar que todavía no era un hecho demasiado mal visto el que alguien pretendiera acceder al estado eclesiástico movido por causas tan poco espirituales. Es el caso, por ejemplo, de Simón Díaz Alfaro, natural de Medina Sidonia y que en 1705 pretendía recibir la primera tonsura, exponiendo como motivo el que habían vacado las capellanías que anteriormente servía un tío suyo y pretendía opositar a las mismas por ser pariente del anterior capellán, Esteban de Alfaro ${ }^{13}$. El conileño Juan

13 ADC, Órdenes, leg. 25, exp. 186. 
Gutiérrez exponía un motivo parecido, puesto que quería recibir la primera tonsura y las dos primeras órdenes menores porque sus padres deseaban y ordenaron que fuera eclesiástico ${ }^{14}$. Y en 1705 el gaditano Juan Joseph de Texada exponía que tenía adjudicada la capellanía fundada por Isabel de Aparicio y Carrillo y que para poderse colar de la misma, y otras más que deseaba, necesitaba recibir la primera tonsura ${ }^{15}$. Otras veces se pretende auxiliar a unos padres ancianos, y, de este modo, ese mismo año Juan Esteban Vacaro y Patrón quería aliviar a sus padres con lo que le produjera una capellanía ${ }^{16}$ y Cristóbal Infante Abendaño quería recibir el subdiaconado porque tenía en la villa de Jimena a su madre y a cinco hermanas "pendientes para su manutención"17. Esta mentalidad tan pragmática comienza lentamente a cambiar a medida que transcurre el siglo XVIII, aunque todavía en 1795 el algecireño Sebastián González declaraba que deseaba recibir las órdenes menores para poder acceder a un patrimonio ${ }^{18}$; pero es el último caso de este tipo que encontramos.

La pauta, por el contrario, comienzan a darla aquéllos que manifiestan el deseo de seguir su vocación o sus anhelos, que en algunos casos son muy tempranos. Antonio Favara manifestaba en 1760 tener inclinación al estado eclesiástico desde que llegó al uso de razón ${ }^{19}$, mientras que el sanroqueño Antonio de la Fuente y Núñez manifestaba en 1795 su deseo de seguir el mismo, "a el que siempre ha tenido la mayor inclinación" ${ }^{20}$. Esta evolución comienza a dar sus frutos en el primer tercio del siglo XIX y el 24,3\% de los aspirantes declara que siempre han deseado o desean convertirse en clérigos. Y en algunos casos les ha costado grandes esfuerzos, como a Francisco Javier Cornejo, asidonense que en 1815 pudo ver coronados sus deseos de llegar al sacerdocio, "siendo el ánimo del suplicante desde sus primeros años seguir el estado eclesiástico, cuya carrera no ha podido abrazar por falta de medios" ${ }^{21}$. Aparecen asimismo motivaciones inéditas hasta entonces, puesto que dos individuos pretenden servir a la Iglesia, y a un pequeño grupo, concretamente a tres, les llama la atención la falta de ministros que hay en sus respectivas parroquias.

A la vez, son relativamente numerosos quienes consideran que la Iglesia es un buen medio para lograr consuelo espiritual (ocho casos), encontrando incluso referencias de servicio al prójimo, según expresaran en 1820 el conileño Juan Melero y Domínguez ("que viendo cerca el término de sus deseos no puede menos que seguir el estado eclesiástico para poderse dedicar de una vez a todas las funciones eclesiásticas y al bien de todos sus prójimos" ${ }^{22}$ ), o el asidonense Sebastián Aguilar de la Flor ("para poderse dedicar de lleno a todas las funciones eclesiásticas, al bien del prójimo y al mayor culto de la Santísima Virgen de la Caridad"23).

El sentido de la evolución parece claro. Si en la primera mitad del siglo XVIII predominaba una idea tan abstracta como la del servicio a la divinidad, en la segunda mitad se extiende la opinión de que el eclesiástico para merecer serlo debe reunir

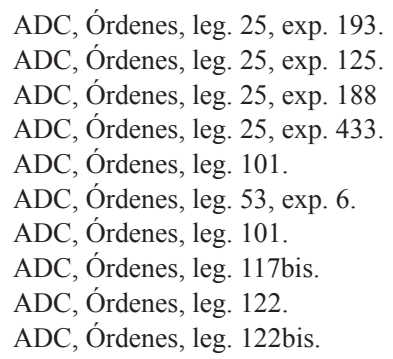


unos requisitos concretos (edad, congrua, etc.), comenzando a extenderse lo que hoy conocemos como vocación. Esta idea va ganando adeptos a medida que transcurre el tiempo, y comienza a extenderse una mentalidad que pretende servir a la Iglesia, lograr un consuelo espiritual, y, por último, servir al prójimo. Servir a los hombres es la gran idea ausente de todo el período, y no es extraño que cuando comienzan a difuminarse ideas tan abstractas como las de servir a la divinidad, se extiendan otras más concretas como las de servir a la Iglesia y al prójimo.

Y algunos, ciertamente, lo hicieron. Los informes que en la década de 1790 redactara el canónigo Cayetano Huarte acerca del bajo clero de la diócesis de Cádiz nos proporcionan una valiosa información acerca del comportamiento cotidiano del cuerpo pastoral del obispado, revelándonos cómo el beneficiado asidonense Joseph Lenzano "cuanto tiene lo da de limosna... su aplicación a el confesionario, púlpito, ejercicios de piedad que ha establecido allí es ejemplar”, en tanto el vicario de la Isla de León, Francisco Castañedo, tuvo un importante papel en el funcionamiento del hospital de dicha población ${ }^{24}$. Pero estos comportamientos de ejemplaridad y servicio, que parecen excepcionales, no deben hacernos olvidar que una golondrina nunca hace primavera.

\section{La edad de ordenación: ¿vocación temprana o hastío del mundo?}

Hace ya muchos años Antonio Domínguez Ortiz, referencia obligada para tantas cosas, $\mathrm{y}$, evidentemente, para el estudio del estamento eclesiástico español durante la Modernidad, señalaba que en ocasiones se ingresaba de pequeño en el estamento eclesiástico, en tanto, en otras ocasiones, la edad y los desengaños de la vida despertaban una vocación tardía ${ }^{25}$, si bien no ofrecía cifras concretas.

Afortunadamente, los expedientes de órdenes nos permiten un acercamiento a esta cuestión, y un caso muy bien estudiado es el de la campiña sevillana, en la cual el promedio de edad es de 17 años para los tonsurados y 26 para los presbíteros. Menos del 20\% de los tonsurados tenía más de 20 años y tan sólo el 1\% más de 30 en el momento de acceder a dicho grado. La presencia de niños resultaba menos extraordinaria que la de aspirantes maduros, y en este caso parece lícito dudar de la autenticidad de las vocaciones tardías, ya que los dos tercios de los tonsurados con más de 30 años no pasaron a las órdenes siguientes por falta de vocación o de congrua, y parece que la mayor parte no persigue el sacerdocio, sino obtener un cierto recogimiento en los últimos años de su vida, tratándose fundamentalmente de viudos o solterones. Por lo que respecta a los presbíteros, dos tercios de los mismos recibe dicha orden con una edad comprendida entre los 23 y los 26 años, y menos de la quinta parte tiene más de treinta. Se suele tardar unos diez años desde la recepción de la primera tonsura hasta el sacerdocio, y las principales causas que impiden culminar la carrera clerical son, en la mitad de los casos, la falta de congrua, $y$, secundariamente, la falta de interés, la ineptitud o la desviación de la conducta ${ }^{26}$.

24 Informe del Visitador Huarte al Obispo sobre la diócesis antes de la visita que iba a practicar este Cádiz abril 14 de 1793, y Confirmación del informe que dio el último visitador Huarte al obispo que practicaba la visita pastoral, Chiclana mayo 11 de 1793 ADC, Secretaría, legajo 507.

25 Domínguez Ortiz, A.: Las clases privilegiadas en el Antiguo Régimen, Madrid, Istmo, 1979, $2^{\circ}$ edición, p. 387.

26 Candau Chacón, op. cit. (nota 11) e Iglesia y sociedad en la campiña sevillana. La vicaría de Écija (1697-1723), Sevilla, Diputación, 1986. 
Por lo que se refiere a la diócesis de Cádiz, el análisis de los expedientes de órdenes fechados entre 1700 y 1834, nos revela cómo, en el caso de la primera tonsura, son muy escasas las ordenaciones tempranas (con menos de diez años de edad), que suponen en torno al 4\% en la primera mitad del siglo XVIII y han desaparecido por completo en el siglo XIX. Por el contrario, hay un neto predominio del grupo de edades comprendido entre los 16 y los 20 años, que a medida que transcurre el tiempo tiende a aumentar su peso, pasando del $42 \%$ en la primera mitad del siglo XVIII, al $52 \%$ en el primer tercio del siglo XIX. Hay, finalmente, un grupo relativamente numeroso de vocaciones tardías, entendiendo como tales la recepción de la tonsura con una edad superior a los 21 años: en torno al $30 \%$ en el siglo XVIII, y algo más del $20 \%$ en el primer tercio del XIX.

En el caso de las órdenes mayores, el concilio de Trento prohibía por completo que nadie accediera a las mismas antes de los veinte y un años, siendo la edad canónica la ya referida para el subdiaconado, un año más para el diaconado, y veinte y tres para el presbiteriado, que supone, como es de sobra conocido, el acceso pleno a la condición sacerdotal. Esto, en líneas generales, se cumplió en la diócesis de Cádiz, salvando algunos casos de individuos que reciben el subdiaconado con una edad situada en torno a los veinte años. La mayoría recibe las órdenes mayores entre los 21 y los 25 años (siempre más del 60\%) y hay un cierto número de vocaciones muy tardías, que se traducen en la recepción de las órdenes mayores con más de treinta años que experimentan un leve aumento, aunque siempre se sitúan, como mucho, en torno al $10 \%$ o incluso menos ${ }^{27}$.

Excepciones, por supuesto, las hay. Una de ellas viene dada por Manuel Gaetano, nacido el 11 de marzo de 1755 y que recibía la primera tonsura y las cuatro órdenes menores el 21 de diciembre de 1804 , a los 49 años de edad ${ }^{28}$. Otras veces es la imposibilidad de obtener una congrua suficiente la que determina el acceso a las órdenes mayores a una edad avanzada, y así le sucedería a Juan Carlos Dorronzoro, nacido el 22 de octubre de 1720 y que en 1738 accedía a las cuatro órdenes menores, si bien hasta 1780 no solicitó la recepción del subdiaconado ${ }^{29}$.

La edad de ordenación no es una cuestión ni mucho menos secundaria. Las ordenaciones tempranas pueden responder a una carrera encauzada de antemano, en tanto que las ordenaciones tardías podrían mostrarnos el hastío y el desengaño por toda una trayectoria vital. Para determinar todo esto sería necesario que los aspirantes a órdenes fuesen más explícitos acerca de sus auténticas motivaciones, pero, lamentablemente, no suelen trascender de la retórica al uso. Uno de ellos será José Gandulfo, que durante muchos años estuvo como comerciante en Sanlúcar, pero que luego abandonaría esta actividad para acceder a la Iglesia en 1795, aunque la renta de la que gozaba (superior a los 10.000 reales anuales) le permitiría disfrutar de un retiro dorado ${ }^{30}$. La Guerra de la Independencia nos brindará algún ejemplo más, y éste sería el caso de Andrés Canosa, que en diciembre de 1805 accedía a la primera tonsura, pero que no persistió en su carrera clerical hasta quince años más tarde, desempeñando en el ínterin una carrera militar que le llevó al grado de sargento pri-

\footnotetext{
Para una visión detallada de estos porcentajes, Morgado García, A., El clero de la diócesis de Cádiz. Estudio de las órdenes sacerdotales (1700-1834), Cádiz, Fundación Municipal de Cultura, 1989, p. 136.

ADC, Órdenes, leg. 78, número 66.

ADC, Órdenes, leg. 85, número 60.

ADC, Órdenes, leg. 101.
} 
mero en el regimiento de Infantería de Sigüenza. Dicho sea de paso, si un aspirante a clérigo no podía haber cometido homicidio alguno, en este caso la situación era diferente al tratarse de franceses, absolviéndole la autoridad eclesiástica de cualquier irregularidad al respecto ${ }^{31}$. Otro caso vendría dado por Juan Manuel Calvo de Núñez, alférez del $19^{\circ}$ Regimiento de Milicias Urbanas, y que en 1815 expresaba "que habiendo sacrificado su persona e intereses en beneficio de la Patria, para sostener los derechos pertenecientes a la Religión y a la Real Persona, finalizada aquella lucha, ha determinado de abrazar la carrera eclesiástica"32.

Pero, por muy llamativas que resulten estas trayectorias individuales, nos seguimos encontrando con golondrinas solitarias. La mayor parte de las biografías, al menos a tenor de lo que podemos deducir de los expedientes de órdenes, son absolutamente planas: el aspirante pasó toda su vida en su localidad natal, allí estudió, y allí pretende ejercer su ministerio clerical.

\section{Muchos son los llamados y pocos los escogidos: la tasa de persistencia ${ }^{33}$}

El acceso al estado sacerdotal no era algo ni mucho menos automático: era necesario seguir un largo camino, a cuyo término no todos llegaban, y algunos ni siquiera lo pretendían. De hecho, hasta el sacerdocio se jalonaban una serie de órdenes y grados como pasos intermedios, aunque algunos los convertían en metas definitivas. La primera tonsura estaba considerada como la puerta de entrada a la carrera clerical, aunque muchos no se ordenaban con posterioridad y solamente pretendían acogerse al fuero eclesiástico o poder acceder a beneficios clericales, por lo que en ciertas diócesis, como la de Sevilla, se establecía un control sobre aquéllos que habían recibido la tonsura otorgándoseles un plazo máximo de tres años para obtener el siguiente grado.

El siguiente paso venía dado por las denominadas órdenes menores, las cuales no eran consideradas aún como un paso definitivo a la condición sacerdotal: el voto de castidad no era necesario, y los minoristas tenían la posibilidad de colgar los hábitos y contraer matrimonio. En la inmensa mayoría de los casos sus motivaciones eran poco espirituales, tales huir de la justicia secular, acogerse al fuero eclesiástico o poseer licencia para el disfrute de algún beneficio, y en este último sentido es de justicia señalar que los autores de la época no recriminaban el acceso a órdenes por cuestiones de necesidad económica. La jerarquía eclesiástica se conformaba con que el cumplimiento de los deberes pertinentes a su estado fuese efectivo, estableciéndose el control de sus conductas por medio de las conferencias morales y las visitas pastorales, pretendiéndose erradicar amancebamientos, trato con mujeres, riñas y hábitos seglares. Su situación era, en muchos casos, lamentable: en una fecha tan tardía como la de 1801 el visitador de la diócesis de Cádiz Cayetano Huarte denunciaba su falta de instrucción y su excesiva propensión a jugar y alborotar con los muchachos

ADC, Órdenes, leg. 122 bis.

ADC, Órdenes, leg. 117 bis.

Se entiende por tasa de persistencia el porcentaje de individuos que llega al presbiteriado en relación con quienes han recibido la primera tonsura. Lo encontramos en Tackett, T.: "Le recrutement du clergé dans le Diocèse du Gap au XVIIIe siécle”, Revue d'Histoire Moderne et Contemporaine, XII (1973), pp. 497-522. 
del pueblo ${ }^{34}$, aunque, niños como eran en la mayor parte de los casos, tampoco se podía esperar más de ellos.

Las obligaciones de los minoristas, en muchas ocasiones, eran meramente teóricas, y las órdenes menores habían perdido buena parte de su sentido originario. El ostiario debía en teoría abrir las puertas del templo, arrojar fuera de la iglesia a los considerados como indignos, tocar las campanas y guardar las vestiduras, aunque en la práctica estas labores han sido traspasadas a sacristanes y campaneros. El lector recibe con este grado la autoridad necesaria para la lectura de los libros sagrados y las profecías. El exorcista tiene la facultad de expulsar a los demonios de los cuerpos de los fieles, aunque ya durante el Antiguo Régimen esta labor era competencia de sacerdotes de profunda preparación intelectual y humana. El acólito, por último, se dedica a administrar las vinajeras con vino y agua en la asistencia del sacrificio de la misa, debiendo además cuidar las luces y transportar los ciriales en algunos casos.

No nos encontramos con propiedad en el estado eclesiástico hasta las tres órdenes mayores, el subdiaconado, el diaconado y el presbiteriado: ya son consideradas como un paso absolutamente irreversible, y el estar ordenado in sacris conllevaba el voto de castidad y la potestad de tocar los vasos sagrados. El subdiácono debía asistir al diácono en el servicio del altar, y participaba en la liturgia de la palabra mediante la lectura de la epístola. El oficio del diácono era proporcionar al sacerdote el cáliz con el vino y la patena con las sagradas formas durante la misa, pudiendo ayudarle en la administración de la eucaristía; y cantar solemnemente el evangelio. El último grado es el del presbiteriado, el sacerdocio plenamente dicho, que califica al ordenado para impartir los sacramentos si recibe las pertinentes licencias, y decir la misa. Para desempeñar un curato, es absolutamente obligatorio ser presbítero, aunque ello no es necesario para gozar de las rentas de una capellanía (aunque sí hay que ser sacerdote para decir las misas correspondientes, si bien siempre se puede subrogar esta obligación), y la misma observación podemos hacer para los beneficios simples.

Era bastante frecuente que muchos individuos recibieran la tonsura o las órdenes menores y no dieran nunca el salto hasta el presbiteriado. En la diócesis de Cádiz, por ejemplo, se ordenaron entre 1700 y 18344.353 tonsurados y solamente 2.637 presbíteros, lo que da una tasa de persistencia ligeramente superior al $60 \%{ }^{35}$. Los datos ofrecidos para la diócesis de Santiago no nos ofrecen un panorama muy distinto, aunque bien es verdad que se parte de unos niveles mucho más reducidos: en 1656-1660 se ordenaron 86 presbíteros y 505 minoristas, en 1750-1754 251 y $526^{36}$. En la de Barcelona en 1546-1570 las cifras serán 4.502 minoristas y 284 presbíteros, para $1635-1717,2,667$ y 622 , y para $1795-1830,757$ y $592^{37}$, siendo de destacar también en este caso el aumento de la tasa de persistencia a medida que avanzamos en el tiempo.

34 Morgado García, A.: Iglesia e Ilustración en el Cádiz del siglo XVIII: Cayetano Huarte (1741-1806), Cádiz, Universidad, 1991.

35 Morgado García, op. cit. (nota 27), p.188.

36 Barreiro Mallón, B.: "Sínodos, pastorales y expedientes de órdenes: tres indicadores de la religiosidad en el noroeste de la Península", en Álvarez Santaló, L. C. y otros (coord..): La religiosidad popular, volumen 2, Barcelona, Anthropos, 1989, pp. 72-95.

37 Badá Elías, J.: "Iglesia y sociedad en el Antiguo Régimen: el clero secular", en Martínez Ruiz, E., y Suárez Grimón, V. (eds): Iglesia y sociedad en el Antiguo Régimen, Gran Canaria, Universidad de Las Palmas, 1994, pp. 81-91; Kamen, H., The Phoenix and the Flame. Catalonia and the Counter Reformation, Yale University Press, 1993. 
Todo parece apuntar que a lo largo de la Modernidad se va haciendo más frecuente la culminación de la carrera eclesiástica, aunque no estamos en condiciones de determinar las motivaciones concretas de esta tendencia, que pueden ir desde una mayor toma de conciencia de las obligaciones clericales como consecuencia del bombardeo doctrinal impuesto por la Reforma católica, hasta una creciente profesionalización de la carrera eclesiástica, tomada como un camino de no retorno, y en la que merece la pena llegar al sacerdocio propiamente dicho, ya que éste es el punto de partida indispensable si se quiere aspirar a curatos, beneficios y prebendas catedralicias. Pero para ello era necesario que se ofreciera un número de puestos suficientes para cubrir la demanda, siendo muy sintomático el hecho de que cuando en 1731 el cabildo municipal de Jimena de la Frontera solicitaba a la curia la reserva de los beneficios simples en los naturales de la localidad, una de las motivaciones expresadas fuese "el aliento de la juventud a las letras con la esperanza del premio" 38 .

\section{¿A qué se renunciaba?: La persistencia de los lazos familiares}

"Fuera del mundo y por encima de sus fieles". Estas palabras, con las cuales Jean Delumeau definió los objetivos últimos de la Reforma Católica en lo que se refería al modelo de comportamiento eclesiástico a alcanzar, resultaron más un ideal de imposible cumplimiento antes que una realidad constatada. Y ello a pesar de que toda una batería de modelos hagiográficos presentaba modelos individuales de clérigos que ya desde sus primeros años habían roto con todos los lazos familiares en aras de obtener un nivel de perfección espiritual que les encaminara a la salvación de su alma $^{39}$. Pero ello era, sencillamente, imposible, habida cuenta de la intrincada maraña de intereses, relaciones, lazos, clientelas, y parentescos que se entrecruzaban en el organigrama interno de la Iglesia durante el Antiguo Régimen.

No perdamos de vista una cuestión, que a veces se olvida: hay que establecer una distinción de partida entre el clero regular y el clero secular (las monjas, habida cuenta de que ofrecen una problemática totalmente diferente, las dejaremos aparte): frente a los primeros, en los cuales, al menos en muchas congregaciones, prima el modelo benedictino de retiro del mundo y de ascetismo, los segundos permanecen en el siglo (de ahí, efectivamente, la denominación que reciben), hasta el punto de que esta permanencia dificultará un poco su eterna salvación. Ya lo señalaba a finales del siglo XVII el obispo de Cádiz José de Barcia y Zambrana, que en su Despertador cristiano, tras comparar el tránsito de este mundo a la vida eterna como un río que hay que cruzar, nos describe cómo

el religioso va por la puente segura de sus votos y reglas. El sacerdote por la barca de sus ejercicios, no tan seguro como el religioso. El superior pasa a caballo con más cuidados y sustos. El casado va nadando y luchando con las aguas de su obligación. El mercader y oficial pasa vadeando muchos peligros, y el súbdito traba-

\footnotetext{
38 “Cádiz 1754. La villa de Jimena sobre patrimonialidad de sus beneficios”, Archivo Histórico Nacional (AHN), Consejos, leg. 15.647 exp. 1.

39 Delumeau, J.: El catolicismo de Lutero a Voltaire, Barcelona, Labor, 1973, p. 272.
} 
jador y pobre llevando a cuestas al superior, y finalmente el rico pasa en hombros ajenos de los pobres $^{40}$.

En realidad, no se renunciaba a mucho. La permanencia en el siglo no hay que entenderla forzosamente como una caída en los peligros de la carne, sino como la adaptación o sujeción, muchas veces obligada, a intereses, relaciones y solidaridades. Son muy significativos al respecto los informes que Cayetano Huarte redactaría del clero rural de la diócesis gaditana en 1791 y $1793^{41}$, a partir de cuya lectura podemos deducir cómo los estrictos modelos de comportamiento que pretendiera imponer la Reforma Católica eran más propios de una Iglesia absolutamente anacoreta que de la Iglesia plenamente imbricada en el mundo que encontramos a lo largo del Antiguo Régimen, a la que era imposible convertir en una inmensa Tebaida. Porque nuestros clérigos, y ello aparece muy bien reflejado en los informes de Huarte, están perfectamente insertos en sus comunidades locales.

Nos los encontraremos adulando a las autoridades (así, el vicario de San Roque Vicente Rodríguez, cuando el general de dicha plaza acudía a oír misa, hacía ir a su casa a dos presbíteros para que le acompañasen a la iglesia), fomentando prácticas devocionales entre la feligresía (en Chiclana el cura más antiguo, Pedro García del Canto, estaba considerado como docto, virtuoso, y muy aplicado a su ministerio, organizando numerosos actos devocionales en la parroquia, como novenas y rezos), aprovechando oportunidades para incrementar sus rentas (Pedro de Castro y Villavicencio, alegando que se trataba de una gracia de 100 pesos anuales concedida por el obispo a fin de que completara con esta suma los escasos emolumentos percibidos como cura, pero dicha concesión había sido meramente verbal y no aparecía ningún justificante de la misma), o manteniendo estrechas relaciones (a veces, más de lo conveniente) con algunos miembros de sus parroquias (en la misma Chiclana, el presbítero Marcos de la $\mathrm{O}$ y Ocaña fue acusado de seducir a una joven de la localidad, pero la madre de ésta se negó a que se procediera judicialmente contra dicho clérigo por temor a que el honor de su hija quedase en entredicho).

Y, al mismo tiempo, sostienen unos contactos muy fluidos con los demás miembros de su estamento (la figura de los vicarios es fundamental en este sentido, por cuanto se encuentra justo en el centro de todo este marco de relaciones), celebrando conferencias morales, repartiéndose las tareas pastorales, y, por qué no decirlo, pleiteando por aquellas cuestiones en las que la economía, la dignidad, o, simplemente, la vanidad, estaban en juego... aunque todo ello es inevitable en ámbitos imbuidos de un fuerte sentido de grupo, por cuanto tiende a confundirse la satisfacción del proyecto vital con el lugar ocupado en el colectivo, sea a través de la autoridad moral, el conocimiento, o la posición jerárquica. Los eclesiásticos, al fin y al cabo, son hombres que ejercen un oficio, $y$, mientras algunos se limitan al estricto cumplimiento de sus obligaciones, otros estarán imbuidos de un notable celo profesional, que a veces se acerca al heroísmo ascético.

No son, ni podían serlo, espíritus puros ni seres angelicales, porque no debemos perder de vista que, ante todo, la Iglesia del Antiguo Régimen es un colectivo de pro-

\footnotetext{
40 Barcia y Zambrana, J. de: Despertador cristiano de sermones doctrinales sobre particulares asuntos dispuesto para que vuelva en su acuerdo el pecador y venza el peligro letargo de sus culpas animándole a la Penitencia, Cádiz, Cristóbal de Requena, 1693, vol. 2, p. 49.

41 Informe del Visitador Huarte al Obispo, ADC, Secretaría, legajo 507.
} 
fesionales plenamente insertos en un mundo al que algunos pretenderán encarrilar doctrinalmente, y en el que otros optarán por salir adelante de la forma más cómoda y placentera posible ${ }^{42}$. Todo muy lejos de la visión postridentina e ilustrada (más coincidentes de lo que podría parecer) de lo que debía ser un cura ideal, y que, en el caso de esta última, sería plasmada en obras literarias de la época como Los enredos de un lugar (1778-1781) de Fernando Gutiérrez de Vegas ${ }^{43}$.

Y una de las cosas que más ataban en este mundo era, obviamente, la familia. Es evidente que un clérigo no podía formar una familia propia, pero en modo alguno se renunciaba a la familia de origen. La propia literatura moral, que tanta importancia tuvo en la formación de una conciencia de grupo en el caso del clero ${ }^{44}$ nos revela que, dentro de este apego a las cosas terrenales, la familia y el parentesco constituían unos lazos que resultaban imposibles de romper ni de soslayar, y que el clérigo no podía en modo alguno ignorar su existencia. Aquí, el punto clave era el de la legitimidad de invertir los frutos de las rentas eclesiásticas en la promoción de la parentela, lo que suele, aunque con matices, ser aceptado por los mismos moralistas: Martín de Azpilcueta, en su conocido Manual de confesores y penitentes, admite que "los puede gastar en remunerar los servicios honestos así de parientes como de extraños. Casar hermanas o parientas pobres con maridos iguales y aún hijas espurias e incestuosas, mas no les puede dar para casar con otro de más alto estado"45.

Los lazos familiares, pues, se mantenían, cuestión que no resulta en modo alguno baladí dada la importancia en la España del Antiguo Régimen del linaje y la parentela como medio de reproducción social, transmisión de patrimonios, perpetuación de status, y mantenimiento de valores sociales. Y, frente a una carrera eclesiástica fruto de una pretendida vocación, la realidad es muy distinta, ya que el ingreso en el estamento dependía en muchas ocasiones de determinadas estrategias familiares por cuanto en las élites (y, muchas veces, no hacía falta llegar tan alto) era bastante frecuente el acceso de los segundones a la Iglesia (el mismo conde duque de Olivares, como es bien sabido, iba encaminado hacia ella hasta el fallecimiento del primogénito de la familia), puesto que se trataba de un medio de evitar la subdivisión del patrimonio familiar, si bien ello podía constituir un arma de doble filo, por cuanto existía el riesgo de sacrificar la continuidad del linaje al celibato eclesiástico ${ }^{46}$. La jerarquía era plenamente consciente de esta situación, ya que los moralistas insistían machaconamente en la obligación de los padres de respetar la vocación de sus retoños, sin que pudieran forzarles, en modo alguno, a ingresar en el estamento clerical. José de Barcia y Zambrana nos lo recuerda continuamente, señalando los peligros de entrar en el sacerdocio con fines turbios, tales el pretender gozar de una vida acomodada o por conveniencias meramente temporales, así como la responsabilidad de los padres,

42 Y la literatura se hace eco de ello en bastantes ocasiones, Cfr. Álvarez Santaló, L. C.: "Vivir como un cura. Algunas precisiones cuantitativas respecto al imaginario social sobre el clero en el siglo XVIII", en Aranda Pérez, F. J. (coord.): Sociedad y élites eclesiásticas en la España Moderna, Cuenca, UCLM, 2000.

43 Fernández, R.: "La clerecía en Los enredos de un lugar, de Fernando Gutiérrez de Vegas", en Fernández, R., y Soubeyroux, J., (eds.): Historia social y literatura. Familia y clero en España (siglos XVIII-XIX), Lleida, Milenio, 2004, pp. 13-38.

44 Irigoyen López, A.: "Los tratados de perfección sacerdotal y la construcción de la identidad social del clero en la España del siglo XVII", Hispania, 230 (2008), pp. 707-734.

45 Azpilcueta y Navarro, M.: Manual de confesores y penitentes, Salamanca, Andrea de Portionariis, 1557, capítulo 25 , "De los clérigos que tienen beneficio".

46 Casey, J.: "Iglesia y familia en la España del Antiguo Régimen”, Chronica Nova, 19 (1991), pp. 71-86. 
que deben examinar la inclinación y el talento de sus hijos, sobrinos o ahijados antes de resolver ordenarles el acceso a la carrera eclesiástica ${ }^{47}$.

Eran, sin embargo, voces que clamaban en el desierto. Es muy sintomático, por ejemplo, que una cuarta parte de los descendientes de los regidores madrileños en el siglo XVII sea destinados a la Iglesia, si bien la proporción decaerá con fuerza en la siguiente centuria ${ }^{48}$. O que nos encontremos en una muestra de 42 familias cacereñas cómo todas ellas, a excepción de una, ofrezcan a sus hijos a la Iglesia como clérigos o monjas, en número de 105 y 248 respectivamente ${ }^{49}$. O que, en el Cádiz dieciochesco, el tiempo medio transcurrido entre el casamiento de los progenitores y el nacimiento del futuro clérigo sea ligeramente superior a los seis años, lo que nos revela cómo muchos de ellos son segundones ${ }^{50}$, figurando, incluso, familias que ofrecen a dos y hasta tres de sus hijos a la Iglesia: los hermanos Pedro y Antonio Legabún fueron tonsurados en 1704 y 1722, en tanto el comerciante Bartolomé Volta tuvo tres hijos clérigos: Antonio Carlos, Juan Bautista (ambos tonsurados en 1740) y Joseph Carlos (que lo fue nueve años más tarde).

Por otra parte, la familia necesitaba al clérigo, hasta el punto de que muchos aspirantes a órdenes declaraban, sin ningún pudor, su deseo de ser ordenados por razones meramente materiales, tales mantenimiento de la familia, padres achacosos, madres viudas, hermanas doncellas o hermanos menores, y, lo que nos resulta más chocante, estos argumentos eran bien comprendidos por todos. Del asidonense Cristóbal Escalante, pretendiente a tonsura en 1624, se decía cómo "será buena obra que se le ordene porque se remedie a su padre y hermanos que tiene pobres" ${ }^{5_{1}}$; del jerezano Francisco López, aspirante al diaconado en 1626, "tiene padre y madre y cuatro hermanos muy pobres que los sustenta de su trabajo"s2; Luis de Ochoa Durán, tarifeño que en 1681 deseaba el presbiteriado, lo justificaba "por ser grande su deseo y hallarse con cortos medios respecto de la suma pobreza de sus padres y que con este medio podrá remediarlos" ${ }^{\prime 3}$. Y, en una fecha tan tardía como la de 1814 el cabildo municipal gaditano apoyaba a Antonio Sistiaga como pretendiente a una prebenda en la catedral, al haber desempeñado el oficio de capellán del batallón ligero de voluntarios de Cádiz, haber sufrido cautiverio algunos años en territorio francés, no haber prestado juramento a Napoleón, y, lo que no era menos importante, tener cuatro hermanas huérfanas y solteras ${ }^{54}$.

Y todo ello nos permite deducir el hecho de que el clero español del Antiguo Régimen mantenía una fuerte vinculación con su núcleo familiar, del que en muchas ocasiones actúa como un elemento de acogida y protección. La función de tío clérigo dentro del sistema familiar del Antiguo Régimen era de gran importancia, ya que los tíos solteros tenían la función de realizar tareas supletorias de tutela paterna y materna, y si esto era parte importante de la estrategia familiar en el caso de los

47 Barcia y Zambrana, op. cit. (nota 40), pp. 293-294, 296-297, 298.

48 Hernández, M.: A la sombra de la Corona. Poder local y oligarquía urbana, Madrid 1696-1808, Madrid, 1993.

49 Rodríguez Sánchez, A.: "El poder y la familia: formas de control y de consanguinidad en la Extremadura de los tiempos modernos", en Chacón Jiménez, F., y Hernández Franco, J., (eds.): Poder, familia y consanguinidad en la España del Antiguo Régimen, Barcelona, Anthropos, 1992, pp. 15-34.

50 Morgado García, A.: Iglesia y sociedad en el Cádiz del siglo XVIII, Cádiz, 1989.

51 ADC, Órdenes, leg. 2.

52 ADC, Órdenes, leg. 2.

53 ADC, Órdenes, leg. 12.

${ }^{54}$ Archivo Municipal de Cádiz (AMC), Actas Capitulares, lib. 174, fols. 185, 413, 421v. 
segundones, más aún lo sería en el caso de los tíos clérigos. Las expectativas entre el clérigo y su grupo familiar eran mutuas, y los servicios recíprocos: el hermano clérigo dará techo a la hermana viuda y ésta le ayudará proporcionándole compañía, afecto y gobierno de la casa; el tío clérigo había vivido en compañía de sus sobrinos y en el momento de la muerte les hará algún legado afectivo o "en efectivo" 55 .

Todo ello se refleja en la amplitud de los núcleos familiares clericales, casi nunca limitados a un eclesiástico aislado: en una diócesis modesta como podía ser la de Coria, veremos que los presbíteros suelen ser cabezas de familia, residiendo con ancianos (los padres), solteronas (hermanas y sobrinas) y jóvenes (sobrinos), con escasa presencia de criados $^{56}$. En Galicia observamos que los hogares clericales presentan un fuerte carácter asistencial, al recoger a una sobrina, una hermana, una madre viuda, un hermano menor, y ofrecerles una solución vital inmediata, siendo el tamaño medio de las familias bastante elevado, al menos cuatro personas, a veces seis $^{57}$. Otras veces, por el contrario, no sucedía así: en Burgos era muy habitual que los clérigos, sobre todo los pertenecientes a los estratos inferiores, vivieran en solitario o a la sombra de algún pariente ${ }^{58}$, lo que no quita que la presencia del servicio doméstico, sobre todo femenino, estuviera sumamente extendida ${ }^{59}$.

En el Cádiz de 1686, de donde contamos con una información muy completa, el tamaño medio de la familia clerical es de 4,79 individuos, ascendiendo el mismo en el cabildo catedralicio a $9,72^{60}$. El clérigo casi nunca vive en solitario (solamente media docena de eclesiásticos de un total superior a doscientos se encuentran en esta situación), y el tamaño de las familias aumenta a medida que ascendemos en la escala clerical, ya que ello se traduce también en mayores medios económicos, por lo que es más factible al eclesiástico proceder a la recogida de parientes que se encuentren en una situación desamparada. Finalmente, señalar que la familia clerical en pocas ocasiones es de un tamaño excesivamente amplio y suele oscilar en torno a las tres o cuatro personas (incluido el clérigo), aunque en el caso del cabildo catedralicio, la élite económica del estamento, sea mucho más frecuente encontrarnos con grupos familiares amplios, con la inclusión de numerosos parientes, criados y esclavos: el canónigo Juan de Balmaseda tenía en 1686 una veintena de personas a su cargo, el también canónigo Antonio García de la Yedra veinte y dos, y el único presbítero que se encuentra en una situación parangonable será Alonso de Guzmán, con catorce individuos conviviendo bajo su techo, incluyendo a su hermana casada, dos sobrinas solteras, dos criadas también doncellas, tres amas, dos esclavos, dos esclavas y dos criados. Se trata, empero, de casos excepcionales, y el tamaño medio familiar no resulta demasiado amplio.

Pero, ¿cuáles son los componentes concretos de estos núcleos familiares? En la

55 Benito Aguado, M. T.: La sociedad vitoriana en el siglo XVIII: el clero, espectador y protagonista, Bilbao, 2001, pp. 109, 125, 166-167.

56 Aragón Mateos, S.: "Notas sobre el clero secular en el Antiguo Régimen. Los presbíteros del obispado de Coria en el siglo XVIII", Hispania Sacra, 89 (1992), pp. 291-334.

57 Dubert García, I.: Historia de la familia en Galicia durante la época moderna, 1550-1830, La Coruña, Ediciós do Castro, 1992.

58 Sanz de la Higuera, F. J.: "Clérigos a la sombra de un pariente en el XVIII burgalés", Hispania Sacra, 120 (2007), pp. 563-594.

59 Sanz de la Higuera, F. J.: "En casa, cama y compañía. Yacer a lomos del siglo XVIII en los hogares eclesiásticos burgaleses", Hispania Sacra, 118 (2006), pp. 545-557.

60 ADC, Varios, Refacciones, caja 3. 
relación anteriormente citada se pormenoriza la composición familiar de la casa de un total de 74 eclesiásticos, de los cuales 25 conviven con ascendientes, 42 con colaterales, 19 con sobrinos, y 55 tienen criados y esclavos a su cargo. Los ascendientes son prioritariamente las madres, casi siempre viudas, y hacia las cuales el clérigo actúa como un factor de protección y recogimiento: veinte clérigos recogen a su madre frente a sólo cinco que acogen a su padre. En el caso de los colaterales, también es evidente este predominio femenino: frente a tres hermanos, nos encontramos con 59 hermanas, de las cuales veinte son mencionadas como doncellas, once como viudas, y solamente una como casada. Dado esta función de acogida, es lógico encontrarnos con una gran cantidad de sobrinos residiendo con los eclesiásticos: nueve sobrinos (dos de ellos huérfanos) y 27 sobrinas (diez de ellas doncellas). Otros parientes, por el contrario, se encuentran mucho menos representados: cinco primas, cuatro tías, un tío, una abuela, y tres mujeres mencionadas en la documentación como "parientas". Esta función de acogida no solamente se limita al marco familiar, ya que es relativamente frecuente encontrarnos a muchachos y muchachas (probablemente se trate de expósitos en la mayor parte de las ocasiones) ${ }^{61}$ recogidos por motivos caritativos o, simplemente, para utilizarlos en el servicio doméstico. De este modo, se mencionan 19 muchachos, un huérfano, dos huérfanas, tres niñas, una muchacha y una doncella. A todo ello se le añade una numerosa servidumbre en la que es habitual el elemento esclavo, predominando nuevamente los componentes femeninos sobre los masculinos: 32 criados, 27 criadas, 37 esclavas, 8 esclavos, nueve negros, cuatro negras, catorce amas, cuatro mujeres y una "mujer mayor".

Y habría que añadir un elemento anómalo, los hijos, muy frecuentes antes de Trento. En el alto clero compostelano, por ejemplo, casi un 15\% de sus miembros tuvo descendencia en la primera mitad del siglo XVI, aunque tras el concilio esta situación se hace mucho menos habitual, si bien nunca desaparecería por completo ${ }^{62}$. En el Cádiz del Seiscientos, Diego García Torrejón reconocía haber tenido una hija natural, María, casada y con treinta años de edad y residente en la villa malagueña de Cortes, fruto de una aventura con "una mujer soltera con quien libremente podía contraer matrimonio"63. Otras veces los hijos son consecuencia de un enlace matrimonial anterior: el escocés Diego Conningan contrajo matrimonio hacia 1684 con Francisca Ignacia de Hinestrosa, ya difunta, hija del regidor Ignacio de Hinestrosa, naciendo de esta relación su hijo Francisco, nombrando al abuelo paterno de éste administrador de los bienes que le tocaren en herencia ${ }^{64}$. El holandés Gerardo Hos se casó en 1651 con la gaditana María de Moncada, naciendo como fruto de esta relación su hija Francisca ${ }^{65}$. En Medina Sidonia, entre los albaceas del clérigo de menores Francisco de Peraza y Ayala figuraba su hijo natural Diego Melchor de Peraza, habido en mujer doncella y al que su madre le proporcionó la suma de 300 ducados para el día que tomara estado ${ }^{66}$. No eran, pues, tan excepcionales estos "hijos de clérigos", aunque la gran pregunta que nos podemos hacer es si los tuvieron antes o después de ingresar

${ }_{61}$ Constatado, entre otros, por Álvarez Santaló, L. C.: Marginación y mentalidad social en Andalucía occidental: expósitos en Sevilla, Sevilla, Consejería de Cultura de la Junta de Andalucía, 1980.

${ }^{62}$ Iglesias Ortega, A.: "La perpetuación de la sangre: la descendencia ilegítima del alto clero compostelano en el siglo XVI”, Manuscrits, 29 (2011), pp. 137-156.

63 AHPC, Protocolos Cádiz, lib. 3105, fol. 945v.

64 AHPC, Protocolos Cádiz, lib. 1436.

65 AHPC, Protocolos Cádiz, lib. 2375, fol. 636.

${ }_{66}$ AHPC, Protocolos Medina, lib. 458, fol. $7 \mathrm{v}$. 
en el estamento: un recuento de las dispensas concedidas por el nuncio a hijos espurios, es decir, hijos de presbíteros y de solteras o viudas, para poder acceder a las sagradas órdenes en los años 1658-1675 arroja un total de 508 casos, concentrándose la mayor parte de las dispensas en Galicia, Asturias, el País Vasco, y los obispados de Astorga y León, y encontrándose los mínimos en la corona aragonesa ${ }^{67}$.

La raíz del problema radica en el hecho de que nunca se pudo terminar con la práctica del concubinato clerical, siendo muy sintomáticas las palabras escritas por Townsend a finales del siglo XVIII según las cuales

en las grandes ciudades los canónigos de las catedrales constituyen los cortejos más importantes, aunque si hay guarnición tienen que conformarse con lo que los militares rechazan. En los pueblos los que dan en esto la pauta, en la medida de sus posibilidades, son los frailes, que no renuncian tampoco a intentarlo en las ciudades. Buena parte del clero de las parroquias es cabeza de familia ${ }^{68}$.

El análisis de los documentos testamentarios nos permite encontrar a muchas mujeres recibiendo pequeños o grandes legados, e incluso siendo nombradas herederas universales, y el mayor o menor nivel de ambigüedad de esta relación nunca lo podremos determinar. Es cierto que la figura del ama de llaves, mujer de edad relativamente avanzada y que estaba a cargo de la casa del clérigo, era algo muy habitual, y hasta los propios diccionarios lo recogían (el de Autoridades, por ejemplo, en 1726, las define como "la mujer a cuyo cargo está el gobierno y cuidado de alguna casa, que ordinariamente recae en mujeres ancianas; y lo más común es tenerla los clérigos y hombres solteros; porque en la casa donde hay señora se llaman mujeres de gobierno"69).

Pero, en otros casos, parece que ni fueron tan mayores ni fueron solamente amas de llaves. Fijémonos, por ejemplo, en algunos miembros del cabildo catedralicio gaditano, como el maestrescuela Juan Nepomuceno Montero de Espinosa, que en 1829 nombraba heredera a Felipa Potier, su ama de gobierno ${ }^{70}$. Lo mismo hacía el racionero Antonio José de la Parra dos años más tarde con Joaquina Walgrove, "de estado honesto que se halla en mi casa y compañía asistiéndome con el mayor cuidado y esmero en la enfermedad que padezco"71. Por su parte, en 1838 el chantre José María Gutiérrez Díaz Noriega nombraba herederas a María Josefa de Orozco y a María del Rosario Herrera, ambas vecinas de la población sevillana de Montellano, por haberle asistido con toda puntualidad durante veinte y ocho años ${ }^{72}$. Estas relaciones estables y permanentes en el tiempo, más o menos discretas, debieron ser más abundantes de lo que parece. En Barcelona, por ejemplo, la mayor parte de los sacerdotes concubinarios tiene este tipo de relaciones públicas de manera sostenida en el tiempo, es decir, que la población las conoce. En el proceso contra el rector de Gornal y

67 Barrio Gozalo, M.: "La Iglesia y los eclesiásticos en la España del Seiscientos. Beneficios y beneficiados", José Alcalá Zamora, y Ernest Belenguer (coords.), Calderón de la Barca y la España del Barroco, Madrid, Centros de Estudios Constitucionales y Sociedad Estatal España Nuevo Milenio, 2001, vol. 1, p. 379.

68 Townsend, J.: Viaje por España en la época de Carlos III (1786-1787), Madrid, Turner, 1988, p. 213.

69 Citado por Irigoyen López, A.: “Aproximación al estudio del servicio doméstico del alto clero de Murcia durante el siglo XVIII”, Obradoiro de Historia Moderna, 19 (2010), pp. 307-327.

70 Archivo Histórico Provincial de Cádiz (AHPC), Protocolos Cádiz, lib. 3205, fol. 1621v.

71 AHPC, Protocolos Cádiz, lib. 599, fol. 472.

72 AHPC, Protocolos Cádiz, lib. 484, fol. 565. 
Bellveny, Clement Gomar, los testigos declaran que hace más de diez o quince años que convive con una mujer, Magdalena y que es fama pública que tienen en común un hijo de once o doce años "y que los saben tots en la villa fins" y que "mossen Gomar ha fet donatio a la dita Magdalena de tots sos bens", para que después esta los pudiera dar a sus hijos ${ }^{73}$. Y es que el fantasma de la soledad debía pesar mucho.

Ahora bien, la persistencia de las vinculaciones familiares no tenía por qué ser obligatoriamente algo negativo. La existencia de todas estas tramas permitía a la Iglesia el mantenimiento de unas relaciones muy fluidas con las élites sociales, lo que permitía la consecución de objetivos comunes y la defensa de unos intereses que, en el fondo, eran bastante parecidos. Y tampoco impidió la existencia (aunque no lo favoreció) de clérigos bien dotados desde el punto de vista intelectual, celosos en el cumplimiento de sus deberes, o preocupados por la situación de sus feligreses. Es muy probable, aunque ello está por determinar, que el concordato de 1753 marcara un fuerte punto de inflexión, sobre todo por el hecho de que las tramas familiares y clientelares serán sustituidas por el surgimiento del Estado como gran patrón, que se asegurará, ciertamente, un importante nivel de control sobre las prebendas y cargos clericales, pero a costa de un precio: la desconexión entre el clero y los poderes locales, y, a la larga, el descenso de la influencia social de la Iglesia. En el siglo XIX, al menos hasta que la situación se normalizara con el concordato de 1851, se pagaría muy cara esta desconexión.

\section{¿A qué se renunciaba?: Una mediana posición económica}

Tampoco se renunciaba a una posición económica al menos mediana, la cual, sin llegar casi nunca a extremos de lujo asiático, sí solía ser superior a la del resto de la población, $y$, sobre todo, ofrecía un importante nivel de seguridad y permitía situarse, relativamente, a salvo de los embates de la coyuntura, justificando el propio discurso clerical esta situación amparándose en que ello supondría una especie de compensación social al llevar un modo de vida especialmente diferenciado del laico por su supuesta renuncia a los parámetros más satisfactorios de la vida seglar, tales la actividad sexual, la procreación, la riqueza y la diversión ${ }^{74}$. El voto de pobreza solamente es extensible a los religiosos (aunque ello es muy relativo, ya que si bien es cierto que el monje es pobre, su orden religiosa respectiva no tiene por qué serlo), aunque es cierto que casi nunca encontraremos al clero entre los grupos sociales más privilegiados desde el punto de vista económico. En Las Palmas de Gran Canarias a mediados del siglo XVIII el capital medio de los inventarios clericales se sitúa en torno a los 138.000 reales, frente a los 135.000 de los comerciantes y más de 462.000 de la nobleza y la oligarquía urbana ${ }^{75}$. En la Huelva del siglo XVII, si el capital medio del grupo clerical asciende a 44.000 reales, el de la hidalguía se eleva a 45.000 , el de los militares a 50.000, y el de los comerciantes a 79.000 , lo que permite incluir al clero en el seno de los grupos medios pero no de

\footnotetext{
Betrán Moya, J. L.: "Entre el orden y el desorden: el clero diocesano barcelonés de la Contrarreforma (15641700)", Studia Historica, 40, 1 (2018), pp. 185-232.

74 Álvarez Santaló, op. cit. (nota 42).

75 Aranda Mendíaz, M.: El hombre del siglo XVIII en Gran Canaria. El testamento como fuente de investigación histórico-jurídica, Las Palmas, Universidad, 1993.
} 
los más privilegiados. Sus capitales están constituidos en un $32 \%$ por inmuebles, predominando ligeramente las tierras sobre las casas, y el $68 \%$ restante por bienes muebles, de los que destacan el dinero en efectivo (el $16 \%$ del capital total) y las deudas a favor (el 26\%), que en ambos casos suponen proporciones superiores a las del conjunto de la sociedad onubense ${ }^{76}$.

Por lo que se refiere a Sevilla, la media de los inventarios clericales supone poco más de 69.000 reales, cifra situada por debajo de todos los demás grupos sociales identificados de la sociedad hispalense (los inventarios postmortem de la nobleza arrojan una cifra superior al millón de reales, los de los comerciantes a unos 750.000 , los de las profesiones liberales a 350.000 y los de artesanos y fabricantes a 206.000) ${ }^{77}$, existiendo además fortísimas diferencias internas, por cuanto el valor de las propiedades de los canónigos duplicaba sobradamente el de las de los curas. Predominan nuevamente los bienes muebles (el 73\% de la fortuna), compuestos fundamentalmente por dinero en efectivo y deudas a favor; en tanto entre los inmuebles predominan abrumadoramente las casas ${ }^{78}$. En la Lérida del Seiscientos, los inventarios clericales se suelen situar en un nivel por encima de agricultores y artesanos, y su descripción nos revela un cierto confort, con un consumo bastante importante y que sobrepasa las meras necesidades del hogar, con un mobiliario diversificado en el que aparecen piezas de escasa difusión en otros grupos sociales, tales bufetes, armarios o camas portátiles, con una gran difusión de objetos meramente decorativos ${ }^{79}$.

En la diócesis de Segovia el status económico de los curas era muy similar al de los funcionarios reales y señoriales del mundo rural, y en la ciudad al grado más elevado del mundo laboral. El párroco de Santo Domingo de Pirón afirmaba en 1773 que, viviendo con moderación, se gastarían unos 5.000 reales anuales, de ellos 3.000 en alimentación, siendo necesario el mantenimiento de dos criadas para el servicio de la casa ${ }^{80}$. En la localidad gaditana de San Fernando, a través de un informe remitido por los curas de la misma en 1769 , se observa que el clero aspiraba a una alimentación abundante y rica en grasas y proteínas (la carne y el tocino son estimados como una necesidad diaria), dos personas a su servicio, dinero suficiente para renovar periódicamente el vestuario y una residencia propia, aunque fuese alquilada, juzgando que para ello se necesitaba una suma de 6.600 reales anuales ${ }^{81}$.

Pero tales deseos chocaban muchas veces con una realidad menos halagüeña: si curas y beneficiados simples, insertos al fin y al cabo en la estructura jerárquica de la Iglesia, podían contar con ingresos suficientes para mantener un mínimo status

76 Lara Ródenas, J. M.: "Mentalidad social y estructura de los capitales en la Huelva del siglo XVII. Una aproximación a través de los inventarios postmortem”, Actas del II Congreso de Historia de Andalucía, Córdoba, Junta de Andalucía/Cajasur, 1995, vol. 8, pp. 345-366.

77 Álvarez Santaló, L. C. y García-Baquero González, A.: "Funcionalidad del capital andaluz en vísperas de la industrialización", Revista de Estudios Regionales, 5 (1980), pp. 101-133.

78 Álvarez Santaló, L. C. y García-Baquero González, A.: "Riqueza y pobreza del clero secular en la Sevilla del Antiguo Régimen (1700-1834)”, Trocadero, 8-9 (1996-1997), pp. 11-46.

79 Santiveri, M., "Niveles de vida material en los grupos socioprofesionales en la Lleida del siglo XVII", en Martínez Shaw, C. (coord..): Historia Moderna, historia en construcción, Lérida, Milenium, 1999, vol. 2, pp. 295-310.

80 Barrio Gozalo, M.: "Las condiciones materiales del clero parroquial del obispado de Segovia en el siglo XVIII. La realidad de los ingresos y los gastos", Investigaciones Históricas, 12 (1992), pp. 113-138.

81 Morgado García, A.: "La Santa Sinodal de 1769. Un intento de mejora del status material del clero secular gaditano”, en Peñalver, M. (coord..): Carlos III, dos siglos después. IV Encuentro de la Ilustración al Romanticismo, Cádiz, Universidad, 1993, vol. 1, pp. 329-338. 
(tengamos en cuenta que en las valoraciones de los ingresos del bajo clero no se incluye el estipendio de la misa diaria, cuyo importe es el doble que el salario cobrado por un obrero agrícola), la situación de los capellanes era mucho menos satisfactoria. Aunque había muchas posibilidades, como la administración de propiedades, o la educación de los hijos de la élite: en el Diario de Madrid son continuas las ofertas de empleo de clérigos que se ofrecen como profesores particulares, y ello debió ser un comportamiento muy generalizado. Así, el presbítero gaditano Diego García Torrejón estuvo corriendo durante 17 años con la administración de los bienes y rentas de Jacome Fantoni, así como con la educación de sus hijos, habiendo percibido durante dicho tiempo la suma de 300 escudos $^{82}$, en tanto que el también presbítero Manuel de Chaves estuvo dos años alojado en la casa del regidor Alonso de la Sierra Vargas Machuca asistiendo a la educación de sus hijos, por lo que recibía la suma de cuatro escudos de plata al mes ${ }^{83}$. El catastro de Ensenada confirma estas dedicaciones profesionales de los clérigos gaditanos, destacando entre las actividades profesionales la medicina y la abogacía ${ }^{84}$. Pero en los medios rurales, el trabajo en el campo era una ocupación mucho más extendida: María Luisa Candau ha constatado cómo en la campiña sevillana, frente a 135 clérigos que son campesinos, hay otros 74 maestros o preceptores, 70 notarios, y, con cifras inferiores, abogados, escribanos, médicos, boticarios, administradores de hospitales, catedráticos, rectores, etc..$^{85}$

En cualquier caso, la conclusión parece evidente: en los casos más favorables el bajo clero estará inserto en una clase media con una posición vital bastante confortable y sin grandes preocupaciones cotidianas, en una situación muy semejante a la de sus homólogos franceses, cuyo nivel medio de vida era equiparable al del artesanado o la pequeña burguesía ${ }^{86}$. Ello no impedirá la subsistencia de un numeroso grupo de capellanes con unos ingresos muy reducidos (en la Sevilla dieciochesca la pobreza amenaza a la cuarta parte del estamento clerical), que deberá verse obligado incluso al trabajo manual para sobrevivir, y con un status de vida no muy distinto del de las clases populares. La carrera eclesiástica casi nunca procurará un enriquecimiento personal, pero sí un buen pasar si se contaba con la buena fortuna de estar inserto al menos en los niveles medios de la jerarquía (lo que era más factible para los grupos mesonobiliarios), contando además con el hecho de que el patrimonio personal podía complementar los ingresos beneficiales percibidos. La mejora económica solamente será notoria si se procede de los grupos peor situados de la sociedad, pero éstos contarán con grandes limitaciones para acceder a los niveles superiores de la jerarquía clerical, y deberán conformarse, en el mejor de los casos, con alguna capellanía sustanciosa o algún beneficio simple o curado cuyo ejercicio apenas brindará posibilidades de promoción posterior.

No era, empero, una mala vida, al menos a partir de los estadios medios del clero. Vivienda independiente, aunque fuese alquilada; reservas monetarias acumuladas, deudas a favor (nacidas muchas veces de pequeños préstamos realizados en

82 AHPC, Protocolos Cádiz, lib. 3195, fol. 945

83 AHPC, Protocolos Cádiz, lib. 20, fol. 108v.

${ }^{84}$ Morgado García, A.: La diócesis de Cádiz de Trento a la Desamortización, Cádiz, Universidad, 2008, pp. $187-$ 188.

85 Candau Chacón, M. L.: "Las fugas del estamento: las grietas de la carrera eclesiástica y los clérigos de paso. Vidas rurales andaluzas en la Edad Moderna”, en Pi Corrales, M. P. y Cepeda Gómez, J. (coord.): Aspectos de la historiografia moderna: Milicia, Iglesia y Seguridad. Homenaje al Dr. Enrique Martínez Ruiz, Madrid, Universidad Complutense, 2018, pp. 99-125.

86 Queniart, J.: Les hommes, l’Eglise et Dieu dans la France du XVIIIe siécle, París, Hachette, 1978. 
el entorno más inmediato: en la pequeña localidad gaditana de Medina Sidonia, los testamentos clericales del siglo XVIII nos revelan cómo un importe total de 263.000 reales es repartido entre 282 deudores, suponiendo, por el contrario, las deudas en contra de los eclesiásticos la suma de 134.000 reales) $)^{87}$, nutrida despensa (jamones, chacinas, aceite y chocolate aparecen regularmente en las casas de los clérigos sevillanos $)^{88} \ldots$ y, lo que no es menos importante, la seguridad de que este buen pasar casi nunca sería perturbado por los avatares de la coyuntura.

Si la vocación conlleva, en mayor o en menor medida, una dosis de renuncia, respondiendo al lema Wir sind nicht auf der Welt, um glücklich zu sein, sondern um unsere Schuldigkeit zu tun" (no estamos en el mundo para ser felices, sino para cumplir nuestro deber $)^{89}$, queda claro que la carrera eclesiástica, al menos en el caso del clero secular, responde más al anhelo de gozar de una posición asegurada y confortable, que de aspirar a un mayor perfeccionamiento espiritual. En su seno no hay que buscar la pobreza (aunque real en muchas ocasiones, nunca elegida), ni la castidad (menos cumplida, seguramente, de lo que parece), y quién sabe si la obediencia. Quien de verdad pretendiera todo ello, debía encaminar sus pasos hacia el convento, no hacia un clero "secular" que nunca abandonó el "siglo".

\section{Bibliografía}

Alemán, M.: Guzmán de Alfarache, edición de Francisco Rico, 2ª edición, Barcelona, Planeta, 1987.

Álvarez Santaló, L. C.: Marginación y mentalidad social en Andalucía occidental: expósitos en Sevilla, Sevilla, Consejería de Cultura de la Junta de Andalucía, 1980.

Álvarez Santaló, L. C.: "Vivir como un cura. Algunas precisiones cuantitativas respecto al imaginario social sobre el clero en el siglo XVIII", en Aranda Pérez, F. J. (coord.): Sociedad y élites eclesiásticas en la España Moderna, Cuenca, UCLM, 2000.

Álvarez Santaló, L. C. y García-Baquero González, A.: "Funcionalidad del capital andaluz en vísperas de la industrialización", Revista de Estudios Regionales, 5 (1980), pp. 101-133.

Álvarez Santaló, L. C. y García-Baquero González, A.: "Riqueza y pobreza del clero secular en la Sevilla del Antiguo Régimen (1700-1834)", Trocadero, 8-9 (1996-1997), pp. 11-46.

Aragón Mateos, S.: "Notas sobre el clero secular en el Antiguo Régimen. Los presbíteros del obispado de Coria en el siglo XVIII", Hispania Sacra, 89 (1992), pp. 291-334.

Aranda Mendíaz, M.: El hombre del siglo XVIII en Gran Canaria. El testamento como fuente de investigación histórico-jurídica, Las Palmas, Universidad, 1993.

Azpilcueta y Navarro, M.: Manual de confesores y penitentes, Salamanca, Andrea de Portionariis, 1557.

Badá Elías, J.: "Iglesia y sociedad en el Antiguo Régimen: el clero secular", en Martínez Ruiz, E., y Suárez Grimón, V. (eds.): Iglesia y sociedad en el Antiguo Régimen, Gran Canaria, Universidad de Las Palmas, 1994, pp. 81-91.

87 Benítez Barea, A.: El bajo clero rural en el Antiguo Régimen (Medina Sidonia, siglo XVIII), Cádiz, Universidad, 2001, pp. 92 y 97.

88 Álvarez Santaló y García-Baquero González, op. cit. (nota 78).

89 Podemos encontrar la cita en Miguel de Unamuno: Del sentimiento trágico de la vida (edición Madrid, Akal, 1983, p. 300), aunque en realidad se debe a Bismarck, que la emplea en una carta escrita a su esposa en 1851 (Matthias, A.: Otto von Bismarck. Sein Leben und sein Werke, Hamburgo, Severus Verlag, 2013, p. 99). 
Barcia y Zambrana, J. de: Despertador cristiano de sermones doctrinales sobre particulares asuntos dispuesto para que vuelva en su acuerdo el pecador y venza el peligro letargo de sus culpas animándole a la Penitencia, Cádiz, Cristóbal de Requena, 1693, vol. 2.

Barreiro Mallón, B.: "Sínodos, pastorales y expedientes de órdenes: tres indicadores de la religiosidad en el noroeste de la Península", en Álvarez Santaló, L. C. y otros (coord..): La religiosidad popular, Barcelona, Anthropos, 1989, vol. 2, pp. 72-95.

Barrio Gozalo, M.: "Las condiciones materiales del clero parroquial del obispado de Segovia en el siglo XVIII. La realidad de los ingresos y los gastos", Investigaciones Históricas, 12 (1992), pp. 113-138.

Barrio Gozalo, M.: "La Iglesia y los eclesiásticos en la España del Seiscientos. Beneficios y beneficiados", en J. Alcalá Zamora, y E. Belenguer (coords.), Calderón de la Barca y la España del Barroco, vol. 1, Madrid, Centros de Estudios Constitucionales y Sociedad Estatal España Nuevo Milenio, 2001, pp. 361-400.

Benítez Barea, A.: El bajo clero rural en el Antiguo Régimen (Medina Sidonia, siglo XVIII), Cádiz, Universidad, 2001.

Benito Aguado, M.T.: La sociedad vitoriana en el siglo XVIII: el clero, espectador y protagonista, Bilbao, 2001.

Betrán Moya, J. L.: "Entre el orden y el desorden: el clero diocesano barcelonés de la Contrarreforma (1564-1700)", Studia Historica. Historia Moderna, 40, 1 (2018), pp. 185-232.

Candau Chacón, M. L.: Iglesia y sociedad en la campiña sevillana. La vicaría de Écija (1697-1723), Sevilla, Diputación, 1986.

Candau Chacón, M. L.: La carrera eclesiástica en el siglo XVIII. Modelos, cauces y formas de promoción en la Sevilla rural, Sevilla, Universidad, 1993.

Candau Chacón, M. L.: El clero rural de Sevilla en el siglo XVIII, Sevilla, Caja Rural, 1994.

Candau Chacón, M. L.: "Las fugas del estamento: las grietas de la carrera eclesiástica y los clérigos de paso. Vidas rurales andaluzas en la Edad Moderna”, en Pi Corrales, M. P. y Cepeda Gómez, J. (coord..): Aspectos de la historiografía moderna: Milicia, Iglesia y Seguridad. Homenaje al Dr. Enrique Martínez Ruiz, Madrid, Universidad Complutense, 2018, pp. 99-125.

Casey, J.: "Iglesia y familia en la España del Antiguo Régimen”, Chronica Nova, 19 (1991), pp. 71-86.

Delumeau, J.: El catolicismo de Lutero a Voltaire, Barcelona, Labor, 1973.

Diccionario de la lengua castellana ...compuesto por la Real Academia Española, tomo sexto, Madrid, Imprenta de la Real Academia Española, 1739.

Domínguez Ortiz, A.: Las clases privilegiadas en el Antiguo Régimen, Madrid, Istmo, 1979.

Dubert García, I.: Historia de la familia en Galicia durante la época moderna, 1550-1830, La Coruña, Ediciós do Castro, 1992.

Durán López, F.: Un cielo abreviado. Introducción crítica a la historia de la autobiografía religiosa en España, Madrid, FUE/Universidad Pontificia de Salamanca, 2007.

Fernández, R.: "La clerecía en Los enredos de un lugar, de Fernando Gutiérrez de Vegas", en Fernández, R. y Soubeyroux, J. (eds.): Historia social y literatura. Familia y clero en España (siglos XVIII-XIX), Lleida, Milenio, 2004, pp. 13-38.

Hernández, M.: A la sombra de la Corona. Poder local y oligarquía urbana, Madrid 16961808, Madrid, Siglo XXI, 1993.

Iglesias Ortega, A.: "La perpetuación de la sangre: la descendencia ilegítima del alto clero compostelano en el siglo XVI”, Manuscrits, 29 (2011), pp. 137-156.

Irigoyen López, A.: "Los tratados de perfección sacerdotal y la construcción de la identidad social del clero en la España del siglo XVII”, Hispania, 230 (2008), pp. 707-734. 
Irigoyen López, A.: “Aproximación al estudio del servicio doméstico del alto clero de Murcia durante el siglo XVIII”, Obradoiro de Historia Moderna, 19 (2010), pp. 307-327.

Irigoyen López, A.: "Sobre el ingreso en el clero: a cuestas con la vocación y con las estrategias familiares en la España del siglo XVIII", Revista de Historia Social y de las Mentalidades, 20, 2 (2016), pp. 101-131.

Isla, J. F. de: Historia del famoso predicador Fray Gerundio de Campazas, ed. de L. Fernández Martín, Madrid, Editora Nacional, 1978, vol. 1.

Julia, D.: "El sacerdote", en Vovelle, M. y otros: El hombre de la Ilustración, Madrid, Alianza, 1995, 359-394.

Kamen, H.: The Phoenix and the Flame. Catalonia and the Counter Reformation, Yale University Press, 1993.

Lara Ródenas, J. M.: "Mentalidad social y estructura de los capitales en la Huelva del siglo XVII. Una aproximación a través de los inventarios postmortem", Actas del II Congreso de Historia de Andalucía, Córdoba, Junta de Andalucía/Cajasur, 1995, vol. 8, pp. 345366.

Matthias, A.: Otto von Bismarck. Sein Leben und sein Werke, Hamburgo, Severus Verlag, 2013.

Morgado García, A.: El clero de la diócesis de Cádiz. Estudio de las órdenes sacerdotales (1700-1834), Cádiz, Fundación Municipal de Cultura, 1989.

Morgado García, A.: Iglesia y sociedad en el Cádiz del siglo XVIII, Cádiz, Universidad, 1989.

Morgado García, A.: Iglesia e Ilustración en el Cádiz del siglo XVIII: Cayetano Huarte (1741-1806), Cádiz, Universidad, 1991.

Morgado García, A.: La diócesis de Cádiz de Trento a la Desamortización, Cádiz, Universidad, 2008.

Morgado García, A.: "La Santa Sinodal de 1769. Un intento de mejora del status material del clero secular gaditano", en Peñalver, M. (coord..): Carlos III, dos siglos después. IV Encuentro de la Ilustración al Romanticismo, Cádiz, Universidad, 1993, vol. 1, pp. 329-338.

Queniart, J.: Les hommes, l'Eglise et Dieu dans la France du XVIIle siécle, París, Hachette, 1978.

Rodríguez Sánchez, A.: "El poder y la familia: Formas de control y de consanguinidad en la Extremadura de los tiempos modernos", en Chacón Jiménez, F., y Hernández Franco, J., (eds.): Poder, familia y consanguinidad en la España del Antiguo Régimen, Barcelona, Anthropos, 1992, pp. 15-34.

Santiveri, M.: "Niveles de vida material en los grupos socioprofesionales en la Lleida del siglo XVII", en Martínez Shaw, C. (coord..): Historia Moderna, historia en construcción, Lérida, Milenium, 1999, vol. 2, pp. 295-310.

Sanz de la Higuera, F. J.: "En casa, cama y compañía. Yacer a lomos del siglo XVIII en los hogares eclesiásticos burgaleses", Hispania Sacra, 118 (2006), pp. 545-557.

Sanz de la Higuera, F. J.: "Clérigos a la sombra de un pariente en el XVIII burgalés", Hispania Sacra, 120 (2007), pp. 563-594.

Tackett, T.: "Le recrutement du clergé dans le Diocèse du Gap au XVIIIe siécle", Revue d'Histoire Moderne et Contemporaine, XII (1973), pp. 497-522.

Torres de Villarroel, D.: Vida, ascendencia, nacimiento, crianza y aventuras, edición de Dámaso Chicharro, Madrid, Cátedra, 1984.

Townsend, J.: Viaje por España en la época de Carlos III (1786-1787), Madrid, Turner, 1988. Unamuno, M. de: Del sentimiento trágico de la vida, Madrid, Akal, 1983. 